\title{
Fine mapping of $R B G 2$, a quantitative trait locus for resistance to Burkholderia glumae, on rice chromosome 1
}

\author{
Ritsuko Mizobuchi $\cdot$ Hiroyuki Sato $\cdot$ \\ Shuichi Fukuoka $\cdot$ Seiya Tsushima $\cdot$ \\ Masahiro Yano
}

Received: 24 December 2014/ Accepted: 8 January 2015/Published online: 20 January 2015

(C) The Author(s) 2015. This article is published with open access at Springerlink.com

\begin{abstract}
Bacterial grain rot (BGR), caused by the bacterial pathogen Burkholderia glumae, is a destructive disease of rice. At anthesis, rice panicles are attacked by the pathogen, and the infection causes unfilled or aborted grains, reducing grain yield and quality. Thus, increasing the level of BGR resistance is an important objective for rice breeding. A quantitative trait locus (QTL) on rice chromosome 1 that controls BGR resistance was previously detected in backcross inbred lines (BILs) derived from a cross between Kele, a resistant traditional lowland cultivar
\end{abstract}

Electronic supplementary material The online version of this article (doi:10.1007/s11032-015-0192-x) contains supplementary material, which is available to authorized users.

R. Mizobuchi $(\bowtie) \cdot$ S. Fukuoka

National Institute of Agrobiological Sciences,

2-1-2 Kannondai, Tsukuba, Ibaraki 305-8602, Japan

e-mail: ritsuko@affrc.go.jp

H. Sato

National Agriculture and Food Research Organization, Kyushu Okinawa Agricultural Research Center (NARO/

KARC), 496 Izumi, Chikugo, Fukuoka 833-0041, Japan

S. Tsushima

National Institute of Agro-Environmental Sciences,

3-1-3 Kannondai, Tsukuba, Ibaraki 305-8604, Japan

M. Yano

NARO Institute of Crop Science (NICS),

2-1-18 Kannondai, Tsukuba, Ibaraki 305-8518, Japan (indica) that originated in India, and Hitomebore, a susceptible modern lowland cultivar (temperate japonica) from Japan. Further genetic analyses using a $\mathrm{BC}_{3} \mathrm{~F}_{6}$ population derived from a cross between a resistant $\mathrm{BIL}\left(\mathrm{BC}_{2} \mathrm{~F}_{5}\right)$ and Hitomebore confirmed that a QTL for BGR resistance was located on the long arm of chromosome 1. To define more precisely the chromosomal region underlying this QTL, we identified nine $\mathrm{BC}_{2} \mathrm{~F}_{6}$ plants in which recombination occurred near the QTL. Substitution mapping using homozygous recombinant and nonrecombinant plants demonstrated that the QTL, here designated as Resistance to Burkholderia glumae 2 (RBG2), was located in a $502-\mathrm{kb}$ interval defined by simple sequence repeat markers RM1216 and RM11727.

Keywords Oryza sativa L. - Disease resistance . Bacterial grain rot - QTL · Linkage analysis ·

Panicle blight

Burkholderia glumae causes bacterial grain rot (BGR) and seedling rot in rice (Oryza sativa L.), both of which are highly destructive to rice production (Ham et al. 2011). Until now, there have been two reports of quantitative trait loci (QTLs) for BGR resistance (Mizobuchi et al. 2013a; Pinson et al. 2010). As described in Mizobuchi et al. (2013a), we detected a QTL for BGR resistance on the long arm of chromosome 1 by using backcross inbred lines (BILs) derived 
from a cross between the traditional lowland indica cultivar Kele (JP13287) and the modern lowland temperate japonica cultivar Hitomebore. The Kele allele at the QTL decreased the ratio of diseased spikelets (RDS).

To validate the effect of the Kele allele at this QTL, we used a resistant BIL $\left(\mathrm{BC}_{2} \mathrm{~F}_{5}\right)$ line (HK19; Fig. 1). Most of the chromosome regions of HK19 originated from the susceptible cultivar Hitomebore, but HK19 also contains a large segment of chromosome 1 and small segments of chromosomes 2, 5, 8, 10,11, and 12 derived from Kele. Twenty-nine $\mathrm{F}_{2}$ plants $\left(\mathrm{BC}_{3} \mathrm{~F}_{6}\right)$ were produced by crossing Hitomebore with HK19. Plants were grown in paddy fields in the summer of 2013 at the National Institute of Agrobiological Sciences (NIAS) in Tsukuba, Japan. Thirty-day-old seedlings were transplanted at a density of one seedling per hill and planted in a single row of 10 hills at a spacing of $18 \mathrm{~cm}$ between hills and $30 \mathrm{~cm}$ between rows. Basal fertilizer was applied at a rate of $56 \mathrm{~kg} \mathrm{~N}, 56 \mathrm{~kg} \mathrm{P}$, and $56 \mathrm{~kg} \mathrm{~K} \mathrm{ha}^{-1}$. Days from

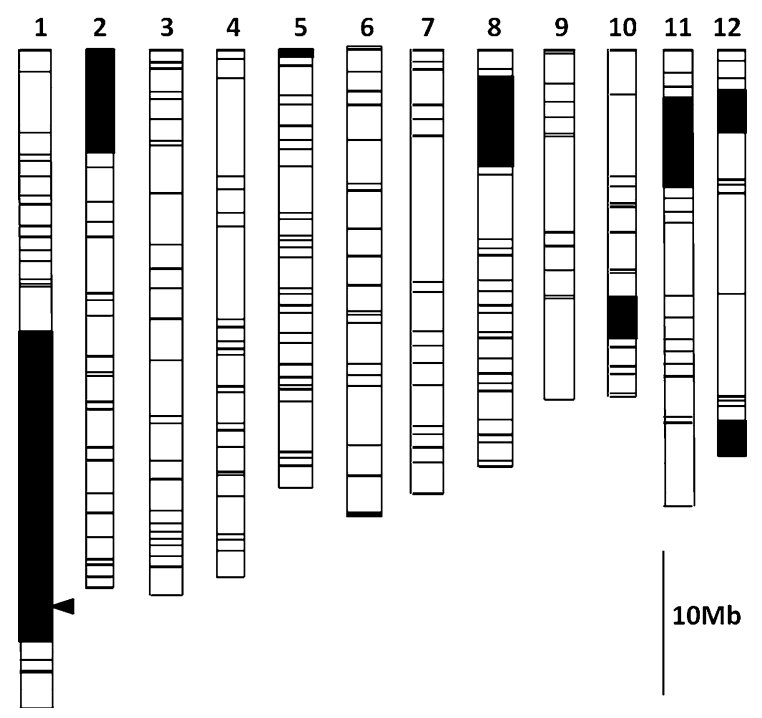

Fig. 1 Graphical genotype of a resistant $\mathrm{BC}_{2} \mathrm{~F}_{5}$ line (HK19) used for fine mapping of QTLs. Chromosome numbers are indicated above each linkage map. Positions of marker loci used for genotyping are shown as horizontal lines and were obtained from the linkage map of BILs derived from a cross between Kele and Hitomebore (Mizobuchi et al. 2013a). The arrowhead next to the long arm of chromosome 1 shows the putative position of the QTL for resistance to bacterial grain rot (BGR) (Mizobuchi et al. 2013a) examined in the present study. White boxes indicate regions homozygous for Hitomebore marker alleles; black boxes indicate regions homozygous for Kele marker alleles sowing to heading for Kele and Hitomebore, which were transplanted on May 15, were 89 and 94 days, respectively. In contrast, days to heading of the $F_{2}$ plants ranged from 99 to 114 days. Therefore, the $F_{2}$ plants were categorized by heading date and inoculated on different dates (from July 26 to August 7). The Kele and Hitomebore controls were seeded and transplanted on several dates after the $\mathrm{F}_{2}$ seeding and transplanting dates to better match the heading dates of the $F_{2}$ plants. We measured resistance to BGR by the modified cut-panicle inoculation method in which panicles containing only spikelets at 1 day after anthesis were harvested and inoculated as previously described (Mizobuchi et al. 2013a). Inoculation and measurement were conducted as previously described (Mizobuchi et al. 2013a). Simple sequence repeat (SSR) markers in the target chromosome regions were screened to identify those detecting polymorphism between Hitomebore and HK19 (IRGSP 2005). The $\mathrm{F}_{2}$ plants were then genotyped with 28 SSR markers (Supplemental Table 1). PCR analysis was performed as previously described (Mizobuchi et al. 2013b). Linkage mapping was performed using version 3.0 of MAPMAKER/EXP software (Lander et al. 1987), and the Kosambi map function was used to calculate genetic distances.

We performed QTL analyses by using composite interval mapping, as implemented by the Zmapqt program (model 6) provided in version 2.5 of the QTL Cartographer software (Wang et al. 2005). By QTL analysis, we detected one QTL between RM11725 and RM11727 on the long arm of chromosome 1 (Fig. 2a). The QTL accounted for $35.4 \%$ of the total phenotypic variance in the $\mathrm{F}_{2}$ plants, and the Kele allele decreased RDS by $10.4 \%$. The $\mathrm{F}_{2}$ plants derived from the cross of Hitomebore and HK19 showed a wide range of variation (20.6-84.7 \%) in RDS (Fig. 2b). The correlation between heading date and RDS was not significant $\left(R^{2}=0.0562\right)$. On the basis of the genotype at RM11727, the SSR marker nearest to LOD peak, $F_{2}$ plants were classified into three genotypic classes; homozygous for the Kele allele, homozygous for the Hitomebore allele, or heterozygous (Fig. 2b). $\mathrm{F}_{2}$ plants homozygous for the Kele allele $(n=8)$ showed a low mean RDS (34.8\%), ranging from 20.8 to $66.8 \%$. Heterozygous plants $(n=9)$ also had a low mean RDS (32.8 \%), ranging from 20.6 to $46.4 \%$. In contrast, the mean RDS was $55.7 \%$, ranging from 27.9 to $84.7 \%$, in plants homozygous for the 


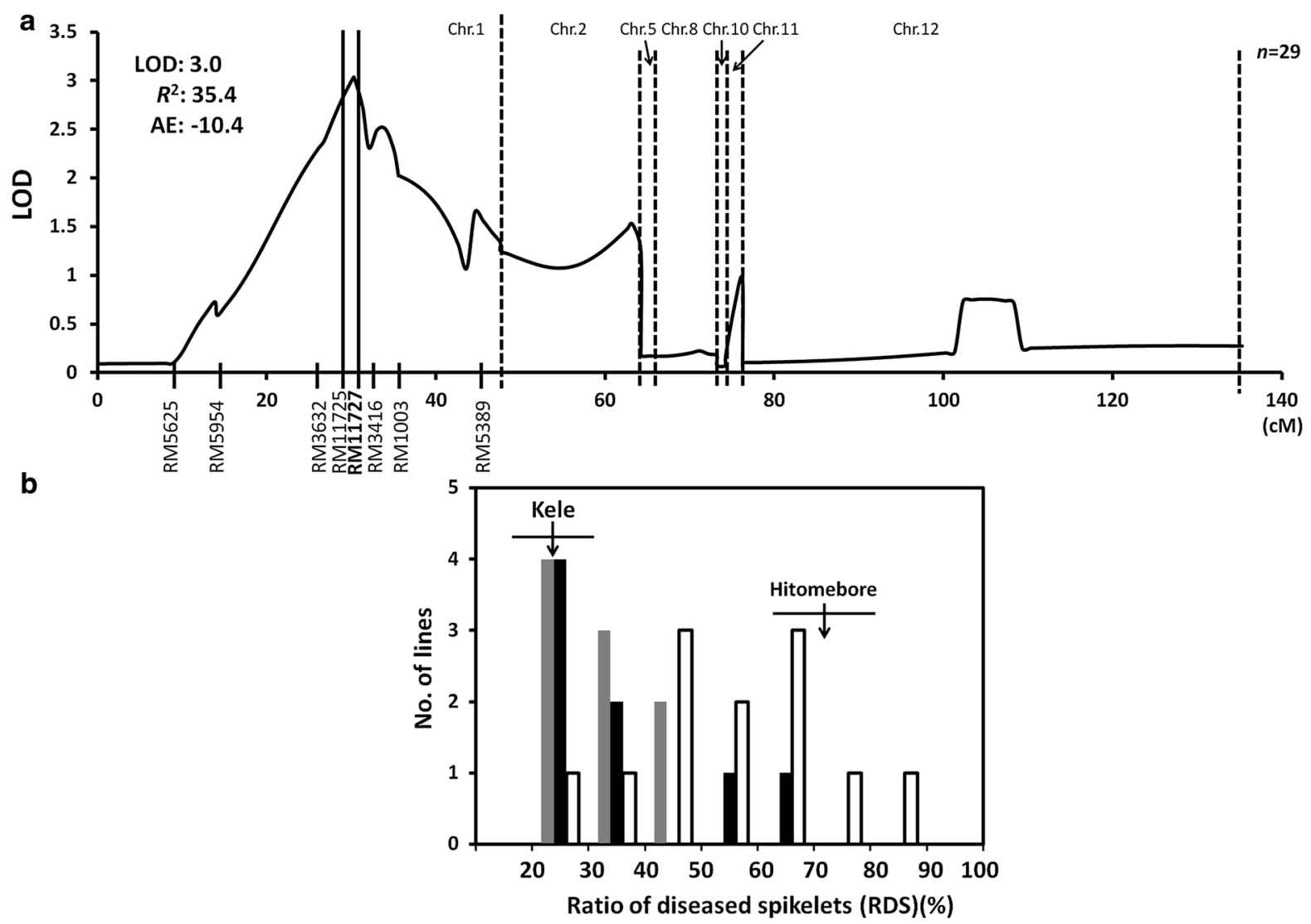

Fig. 2 Chromosomal location of a QTL for resistance to bacterial grain rot (BGR) on the long arm of chromosome 1 and effects of allelic differences at linked marker RM11727. a The log-likelihood curve indicates a putative QTL position on chromosome 1 in an $\mathrm{F}_{2}$ population derived from Hitomebore $\times$ HK19 (a resistant $\mathrm{BC}_{2} \mathrm{~F}_{5}$ line). We used genome-wide threshold values $(\alpha=0.05)$ to detect putative QTLs on the basis of the results of 1,000 permutations. $L O D$ logarithm of odds, $R^{2}$ percentage of phenotypic variance explained, and $A E$ additive effect of the allele from Kele relative to that from Hitomebore.

Hitomebore allele $(n=12)$. Thus, plants homozygous for the Kele allele tended to show lower RDS values than those homozygous for the Hitomebore allele. These results clearly support the existence of the previously detected QTL on the long arm of chromosome 1 and show that the Kele allele at the QTL decreases the RDS.

To further delimit the candidate genomic region of the QTL for BGR resistance, we used a BIL $\left(\mathrm{BC}_{2} \mathrm{~F}_{5}\right)$ line (HK114) in which the region of interest on the long arm of chromosome 1 was heterozygous (Supplemental Fig. 1). We identified nine recombinants $\left(\mathrm{BC}_{2} \mathrm{~F}_{6}\right)$ from the BIL line and then selected b Frequency distribution of the ratio of diseased spikelets (RDS) in $F_{2}$ plants showing the three genotype classes of SSR marker RM11727, which was found to be nearest to LOD peak. The $x$ axis labels indicate the maximum RDS in each bin. Genotypes at RM11727 are represented as white bars (homozygous for Hitomebore allele), gray bars (heterozygous), and black bars (homozygous for Kele allele). The RDS values of the $\mathrm{F}_{2}$ plants were scored 5 days after inoculation. Arrows indicate the mean values for Kele and Hitomebore; horizontal lines across the arrows indicate the standard deviations

homozygous recombinant and nonrecombinant plants from the $\mathrm{BC}_{2} \mathrm{~F}_{7}$ progeny of each one. Thus, we evaluated nine pairs of lines in the inoculation test. Significant difference about RDS was detected among seven pairs $\left(\mathrm{BC}_{2} \mathrm{~F}_{7}-12 \mathrm{~W}-1,-2,-3,-5,-6,-7\right.$, and -8$)$, whereas two pairs $\left(\mathrm{BC}_{2} \mathrm{~F}_{7}-12 \mathrm{~W}-4\right.$ and -9$)$ had high RDS values that were not significantly different between those of the recombinant and nonrecombinant lines (Fig. 3). Together, the genotype and phenotype information clearly delimit the QTL for BGR resistance between SSR markers RM1216 and RM11727 (a 502-kb interval in the Nipponbare genome reference sequence) on chromosome 1 


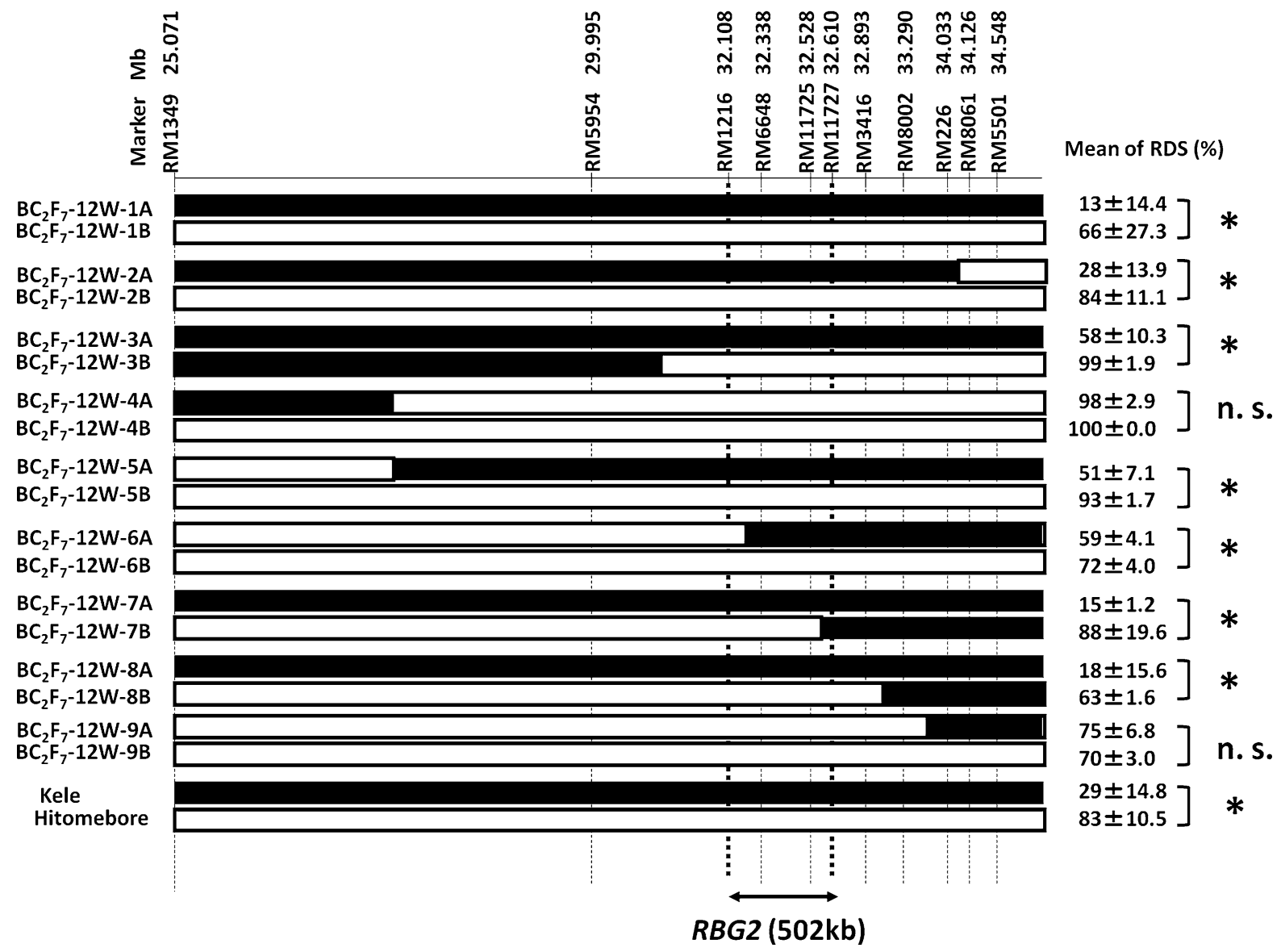

Fig. 3 Substitution mapping of a QTL controlling resistance to bacterial grain rot (BGR) on the long arm of chromosome 1 in recombinant $\mathrm{BC}_{2} \mathrm{~F}_{7}$ lines. Each pair of lines (e.g., $1 \mathrm{~A}$ and $1 \mathrm{~B}$ ) was identified from the progeny of a recombinant $\mathrm{BC}_{2} \mathrm{~F}_{6}$ plant. Black bars indicate chromosome regions derived from Kele (resistant); white bars indicate chromosome regions derived from Hitomebore (susceptible). Positions are based on the

(Fig. 3). Because we have already identified and named RBGI (Resistance to Burkholderia glumae 1; formerly named qRBS1), a QTL on chromosome 10 involved in resistance to bacterial seedling rot (Mizobuchi et al. 2013b), we have designated this QTL for BGR resistance as Resistance to Burkholderia glumae 2 (RBG2), following the nomenclature recommended by McCouch and CGSNL (Committee on Gene Symbolization 2008).

We surveyed the candidate genomic region of $R B G 2$ using the Rice Annotation Project Database (http://rapdb.dna.affrc.go.jp/ (Ohyanagi et al. 2006)) to nominate candidate genes. Among the predicted genes, there are none known to be related to disease
International Rice Genome Sequencing Project (IRGSP) 1.0 pseudomolecules of the Nipponbare genome. The location of the candidate QTL ( $R B G 2)$, indicated at the bottom, is based on the phenotypic data obtained in an inoculation test, tabulated on the right. The ratio of diseased spikelets (RDS) scores of the two lines in each pair was compared by using Student's test. $* P<0.05 ; n s$ not significant, $P>0.05$

resistance such as nucleotide-binding-site-leucinerich repeat (NBS-LRR) genes. It is hard to predict which of the genes might be related to BGR resistance because there have been no reports of genes associated with BGR resistance and because the morphological and physiological functions of $R B G 2$ are not yet known. Thus, further delimitation of the candidate genomic region of $R B G 2$ will be necessary to identify the gene corresponding to $R B G 2$.

Since B. glumae was first discovered in Japan (Goto and Ohata 1956; Goto et al. 1987; Kurita and Tabei 1967; Uematsu et al. 1976), it has also been reported in other countries in East Asia (Chien and Chang 1987; Cottyn et al. 1996a, b; Jeong et al. 2003; Luo et al. 
2007; Trung et al. 1993) and Latin America (Nandakumar et al. 2007b; Zeigler and Alvarez 1989). Although several cultivars show partial resistance to BGR (Goto and Watanabe 1975; Groth et al. 2007; Imbe et al. 1986; Mogi and Tsushima 1985; Nandakumar et al. 2007a; Nandakumar and Rush 2008; Pinson et al. 2010; Prabhu and Bedendo 1988; Sayler et al. 2006; Sha et al. 2006; Takita et al. 1988; Wasano and Okuda 1994; Yasunaga et al. 2002), only one report of QTL analysis of BGR resistance has been published other than our previous report (Mizobuchi et al. 2013a; Pinson et al. 2010). This may be because the level of resistance is highly influenced by environmental conditions, making genetic analysis of BGR resistance very difficult (Tsushima 1996; Tsushima et al. 1985). Pinson et al. (2010) found a major QTL on chromosome 3 for BGR resistance colocated with a QTL for heading date. Because lateflowering panicles are subjected to cooler temperatures that are less conductive to disease development during grain fill, it is possible that the genetic effects of the heading-related QTLs affected the disease scoring. On the other hand, by selecting parental cultivars with similar heading dates and using a method (cut-panicle inoculation) that minimizes the effect of heading date variation, we successfully detected a major QTL for BGR resistance on chromosome 1, and no QTL for heading date was detected near this BGR resistance QTL (Mizobuchi et al. 2013a). In the QTL analysis of this study, the correlation between heading date and RDS was not significant $\left(R^{2}=0.0562\right)$. The nine pairs of $\mathrm{BC}_{2} \mathrm{~F}_{7}$ lines used for substitution mapping had similar heading dates between homozygous recombinant and nonrecombinant plants. Therefore, we suppose that the disease resistance derived from $R B G 2$ is not a pleiotropic effect of the QTL for heading date. To enhance our understanding of the genetic control of BGR resistance, we undertook fine mapping of the QTL and successfully defined a candidate genomic region for the QTL, RBG2. The RBG2 map information obtained in this study opens the way not only for the use of $R B G 2$ in breeding programs, but also for gene isolation that will enable us to elucidate the genetic mechanism of BGR resistance.

Acknowledgments We thank Dr. T. Imbe (NARO) for valuable advice. We also thank the staff of the technical support section of the NIAS for their field management and experimental support. This work was supported by grants from the Ministry of Agriculture, Forestry and Fisheries of Japan
(Project for Climate Change, Rice-2006 and Rice-3003) and the NIAS Strategic Research Fund.

Conflict of interest The authors declare that they have no conflict of interest.

Open Access This article is distributed under the terms of the Creative Commons Attribution License which permits any use, distribution, and reproduction in any medium, provided the original author(s) and the source are credited.

\section{References}

Chien CC, Chang YC (1987) The susceptibility of rice plants at different growth stages and 21 commercial rice varieties to Pseudomonas glumae. J Agric Res China 36:302-310

Cottyn B, Cerez MT, VanOutryve MF, Barroga J, Swings J, Mew TW (1996a) Bacterial diseases of rice. 1. Pathogenic bacteria associated with sheath rot complex and grain discoloration of rice in the Philippines. Plant Dis 80 : 429-437

Cottyn B, VanOutryve MF, Cerez MT, DeCleene M, Swings J, Mew TW (1996b) Bacterial diseases of rice. 2. Characterization of pathogenic bacteria associated with sheath rot complex and grain discoloration of rice in the Philippines. Plant Dis 80:438-445

Goto K, Ohata K (1956) New bacterial diseases of rice (brown stripe and grain rot). Ann Phytopathol Soc Jpn 21:46-47

Goto T, Watanabe B (1975) Varietal resistance to bacterial grain rot of rice, caused by Pseudomonas glumae. Proc Assoc Plant Prot Kyushu 21:141-143 (in Japanese)

Goto T, Nishiyama K, Ohata K (1987) Bacteria causing grain rot of rice. Ann Phytopathol Soc Jpn 53:141-149

Groth DE, Linscombe SD, Sha X (2007) Registration of two disease-resistant germplasm lines of rice. J Plant Regist 1:63-64. doi:10.3198/jpr2006.10.0677crg

Ham J et al (2011) Molecular genetic and genomic studies on bacterial panicle blight of rice and its causative agent Burkholderia glumae. Phytopathology 101:S266-S266

Imbe T, Tsushima S, Nishiyama H (1986) Varietal resistance of rice to bacterial grain rot and screening method. Proc Assoc Plant Prot Kyushu 32:17-19

IRGSP (2005) The map-based sequence of the rice genome. Nature 436:793-800

Jeong Y, Kim J, Kim S, Kang Y, Nagamatsu T, Hwang I (2003) Toxoflavin produced by Burkholderia glumae causing rice grain rot is responsible for inducing bacterial wilt in many field crops. Plant Dis 87:890-895

Kurita T, Tabei H (1967) On the pathogenic bacterium of bacterial grain rot of rice. Ann Phytopathol Soc Jpn 33:111

Lander E, Green P, Abrahamson J, Barlow A, Daley M, Lincoln S, Newburg L (1987) MAPMAKER: an interactive computer package for constructing primary genetic linkage maps of experimental and natural populations. Genomics $1: 174-181$

Luo J, Xie G, Li B, Lihui X (2007) First report of Burkholderia glumae isolated from symptomless rice seeds in China. Plant Dis 91:1363. doi:10.1094/Pdis-91-10-1363b 
McCouch S, CGSNL (Committee on Gene Symbolization. Nomenclature and Linkage, Rice Genetics Cooperative) (2008) Gene nomenclature system for rice. Rice 1:72-84

Mizobuchi R, Sato H, Fukuoka S, Tanabata T, Tsushima S, Imbe T, Yano M (2013a) Mapping a quantitative trait locus for resistance to bacterial grain rot in rice. Rice 6:13. doi:10. 1186/1939-8433-6-13

Mizobuchi R, Sato H, Fukuoka S, Tsushima S, Imbe T, Yano M (2013b) Identification of $q R B S 1$, a QTL involved in resistance to bacterial seedling rot in rice. Theor Appl Genet 126:2417-2425. doi:10.1007/s00122-013-2145-2

Mogi S, Tsushima S (1985) Varietal resistance to bacterial grain rot in rice, caused by Pseudomonas glumae. Kyushu Agric Res 47:103

Nandakumar R, Rush MC (2008) Analysis of gene expression in Jupiter rice showing partial resistance to rice panicle blight caused by Burkholderia glumae. Phytopathology 98:S112

Nandakumar R, Bollich P, Groth D, Rush MC (2007a) Confirmation of the partial resistance of Jupiter rice to bacterial panicle blight caused by Burkholderia glumae through reduced disease and yield loss in inoculated field tests. Phytopathology 97:S82-S83

Nandakumar R, Rush MC, Correa F (2007b) Association of Burkholderia glumae and B. gladioli with panicle blight symptoms on rice in Panama. Plant Dis 91:767. doi:10. 1094/Pdis-91-6-0767c

Ohyanagi $\mathrm{H}$ et al (2006) The rice annotation project database (RAP-DB): hub for Oryza sativa ssp japonica genome information. Nucl Acids Res 34:D741-D744. doi:10.1093/ Nar/Gkj094

Pinson SRM, Shahjahan AKM, Rush MC, Groth DE (2010) Bacterial panicle blight resistance QTLs in rice and their association with other disease resistance loci and heading date. Crop Sci 50:1287-1297. doi:10.2135/cropsci2008. 07.0447

Prabhu AS, Bedendo IP (1988) Glume blight of rice in Brazil: etiology, varietal reaction and loss estimates. Trop Pest Manag 34:85-88
Sayler RJ, Cartwright RD, Yang YN (2006) Genetic characterization and real-time PCR detection of Burkholderia glumae, a newly emerging bacterial pathogen of rice in the United States. Plant Dis 90:603-610. doi:10.1094/Pd-900603

Sha X et al (2006) Registration of 'Jupiter' rice. Crop Sci 46:1811-1812. doi:10.2135/cropsci2005.10-0393

Takita T, Imbe T, Nishiyama H, Tsushima S (1988) Resistance to rice bacterial grain rot in indica and upland rice. Kyushu Agric Res 50:28

Trung HM, Van NV, Vien NV, Lam DT, Lien M (1993) Occurrence of rice grain rot disease in Vietnam. Int Rice Res Notes 18:30

Tsushima S (1996) Epidemiology of bacterial grain rot of rice caused by Pseudomonas glumae. JARQ 30:85-89

Tsushima S, Mogi S, Saito H (1985) Effects of inoculum density, incubation temperature and incubation period on the development of rice bacterial grain rot. Proc Assoc Plant Prot Kyushu 31:11-12

Uematsu T, Yoshimura D, Nishiyama K, Ibaraki T, Fujii H (1976) Occurrence of bacterial seedling rot in nursery flat, caused by grain rot bacterium Pseudomonas glumae. Ann Phytopathol Soc Jpn 42:310-312

Wang S, Basten C, Zeng Z (2005) Windows QTL cartographer 2.5. Department of Statistics, North Carolina State University, Raleigh. http://statgen.ncsu.edu/qtlcart/WQTL Cart.htm

Wasano K, Okuda S (1994) Evaluation of resistance of rice cultivars to bacterial grain rot by the syringe inoculation method. Breed Sci 44:1-6

Yasunaga T, Wada T, Oosata KF, Hamachi Y (2002) Varietal differences in occurrence of bacterial grain rot in rice cultivars with high palatability. Crop Sci Soc Jpn 68:12-14

Zeigler RS, Alvarez E (1989) Grain discoloration of rice caused by Pseudomonas glumae in Latin America. Plant Dis 73:368 